\title{
The Modality System and the Emotional Appeals: An Interpersonal Interpretation of Roosevelt's Speeches
}

\author{
Xiaoli Dou \\ School of Foreign Languages, Chongqing Normal University, China \\ Wendi Yang \\ Chengdu Qinglong Subbranch, Industrial and Commercial Bank of China, Ltd., China
}

\begin{abstract}
This article takes Franklin D. Roosevelt's four inaugural speeches as objects of study, and mainly uses the modality system in Halliday's systemic functional grammar as theoretical framework. This paper, from a functional-stylistic perspective, tries to investigate the close relationship between the modality system and the interpersonal function, i.e. its emotional appeals to the audience, underlying those typical linguistic markers, hence to uncover Roosevelt's unmatched linguistic competence and speaking techniques. Our study shows that Roosevelt prefers modalization to modulation. As for modulation, obligation covers $18.70 \%$ signaling the speaker's degree of pressure on the audience to take positive action, and inclination appears frequently, covering $13.01 \%$, and is mainly realized by finite modal operators or adjectives, showing Roosevelt's willingness to do something for his country and people. Through these sparkling speeches, his wisdom and intelligence, capability and responsibility, prestige and power are fully demonstrated.
\end{abstract}

Index Terms-Roosevelt's four inaugural speeches, modality system, stylistic effects, emotional appeals

\section{INTRODUCTION}

Franklin D. Roosevelt was one of the three greatest presidents in American history, who held the presidential post for four terms. His political achievements won his high supporting rate throughout the United States. Particularly, Roosevelt's eloquence receives great reputation all over the world. The countless brilliant speeches in his life helped him climb up the ladder of success. Roosevelt's four online inaugural speeches stand out from his speeches, including his 1933 inaugural address in Great Depression, 1937 inaugural address just after Great Depression, 1941 inaugural address calling for domestic safety and 1945 inaugural address for peace. Through these sparkling speeches, his wisdom and intelligence, capability and responsibility, prestige and power are fully demonstrated. Such Scholars as Campbell and Jamieson (1990), Lemke (1992), Hoye (1997), and others, have shown an enduring interest in exploring public speech texts and have made some fruitful results. This paper, from a functional-stylistic perspective, tries to investigate the close relationship between the modality system and the interpersonal function, i.e. its emotional appeals to the audience, underlying those typical linguistic markers, hence to uncover Roosevelt's unmatched linguistic competence and speaking techniques.

\section{The Modality System}

Modality is considered as a chief exponent of Interpersonal Function and widely studied. According to Lyons, It was first recognized in traditional modal logic propositions as the notion of necessity and possibility. So, modality in logic is based on the concepts of necessity and possibility and this id typical view of modality that linguists from generally accept.

According to Halliday, modality system is one main way to realize the Interpersonal Function. It is a form of participation of the speaker in the speech event. Halliday defined modality as the intermediate degree between the positive and the negative poles, such as 'sometimes' or 'maybe'. (Halliday, 2000, p. 88) He defines that the first is called modalization, whereas the second is referred as modulation.

\section{A. Modalization}

There are two types of modalization: 1) degrees of probability and 2) degrees of usuality. Probability, which means how likely it is to be true, is equivalent to either "yes" or "no", with different degrees of likelihood attached. Some of the basic words to show probability scale are: possible/ probable/ certain. Usuality, which means how frequency it is true, is equivalent to both "yes "and "no", with different degrees of oftenness attaches, and some typical words: sometimes/often/ always. 
There are two kinds of intermediate possibility. So there are two types of modulation. They are degrees of obligation and degrees of inclination, depending on the speech function, whether command or offer. Modulation expresses the speaker's obligation or inclination to exchange goods or services by offering or requiring the listener to offer, or advising both sides to do something. It is the speaker's judgment of the desirability of the proposal.

According to Halliday, it is possible to establish three basic values of modality: high, median and low. (Halliday, 1994, p. 358) Besides, Thompson talks about modality as involving degrees and scales (2000: 59). The speaker may, for example, signal a higher or lower degree of certainty about the validity of a proposition ('it will / may rain'); or a higher or lower degree of pressure on the other person to carry out a command ('you must / should leave'). Values of modality can be arranged in a gradable way from low to high, which can manifest the intensity of the language user's engagement in the negotiation.

Orientation is the basic distinction that determines how modalization and modulation will be realized. It is the subjective and objective or explicit and implicit variables of modality. Probability, usuality, obligation and inclination can all be expressed by the metaphor with the combination of the four orientations. Here are four examples.

(1) I want her to know it.

Subjective/explicit

(2) She should know it.

Subjective/implicit

(3) It is likely that he knows it.

(4) He probably knows it.

Objective/ explicit

Objective/ implicit

Both types of modulation can be expressed in two ways. i) by a finite modal operator, e.g. you should do that, I will buy the bag; ii) by an expansion of the predicator such as a passive verb or an adjective, e.g. you are supposed to do it, I am anxious to buy the bag. In a word, modality refers to a speaker's opinion about or attitude towards, the truth of a proposition or desirability of the proposal expressed by a sentence. It extends to their attitude towards the situation or event depicted by a sentence, too.

\section{The Modality System In RooseVelt's SpeEcheS}

\section{A. Modality}

Modality, as an independent part of interpersonal function, refers to the speaker's judgments, attitudes or intentions towards a linguistic event. Orientation and value are two variables of modality. Especially values of modality are rated conveniently into three scales: high, median and low. This following section will study them in detail to find different interpersonal meanings.

At first, in order to obtain a comprehensive understanding of modality choices in these addresses, this section makes a quantitative analysis of the modal expressions in the sample addresses. The modal expressions in the four sample addresses are exhibited in the following Table 4.

TABLE 4:

A STATISTICAL TABLE OF RoOSEVELT's 4 SPEECHES

\begin{tabular}{|c|c|c|c|c|}
\hline \multirow{2}{*}{$\begin{array}{l}\text { Modality Type } \\
\text { Sample No. }\end{array}$} & \multicolumn{2}{|c|}{ Modalization } & \multicolumn{2}{|l|}{ Modulation } \\
\hline & Probability & Usuality & Obligation & Inclination \\
\hline 1 & 35 & 1 & 11 & 11 \\
\hline 2 & 19 & 2 & 5 & 2 \\
\hline 3 & 8 & 1 & 5 & 0 \\
\hline 4 & 15 & 3 & 2 & 3 \\
\hline Total times & 77 & 7 & 23 & 16 \\
\hline Percentage & $62.60 \%$ & $5.69 \%$ & $18.70 \%$ & $13.01 \%$ \\
\hline
\end{tabular}

From the statistics, we can see that the respective percentages of probability, usuality, obligation and inclination are $62.60 \%, 5.69 \%, 18.70 \%$ and $13.01 \%$. Table 4 indicates that the frequency of modalization is $68.29 \%$, more frequently than modulation which only takes up $31.71 \%$ of the total. It means that Roosevelt gives more propositions than proposals in these addresses. Thus, it can be concluded that in the four inaugural addresses, what Roosevelt conveys to the hearers more is information, while request and command is relatively less. The layout corresponds with every theme and every historical background of the inaugural addresses. At the time of the first inaugural address (Sample 1), Roosevelt assumed the Presidency during the Great Depression and Roosevelt called on his people to be loyal to his country. He brought hope to Americans and asserted exciting words, "the only thing we have to fear is fear itself." It comes to the second inaugural address (Sample 2) when the United States gets through the Great Depression. Roosevelt calls for Americans to adhere to democracy and inspire good-will in view of moral decadency. As a civilized country, the United States should make every American citizen the subject of his country' interest and concern. Taking the oath of office as President of the United States for the third time (Sample 3), Roosevelt claims that 'in this day the task of the people is to save that Nation and its institutions from disruption from without". He affirms domestic safety maintained by wealth and clearly warns interruption from abroad. In the face of great perils, he appeals to Americans to perpetuate the integrity of democracy and resort to foreign policy. When making his fourth inaugural address (Sample 4), Roosevelt put great emphasis on peace. He announces that we Americans, together with our allies, shall work and fight for a durable and honorable peace. And he believes that Americans will achieve such a peace because of essential democracy. 
In every inaugural address, Roosevelt is mainly concerned with propositions which conveys information about American situation of the day and makes government fundamental policy at different time known to the public. As the highest executive of the country, he hopes to persuade the public to accept and support his policy in a desirable relationship with the audience. Thus, Roosevelt applies fewer proposals, which is the common technique of political speeches serves the multiple purposes of general inaugural addresses.

\section{Probability}

Expression of probability appears most frequently taking up $62.60 \%$ of all the modality in the samples. Probability is mainly realizes by finite modal verb operators in our samples. Through the careful study, we find that will, can, may are the most frequent modals in expressing probability. Will, can, may appear 25times, 28times and 10times respectively and their corresponding percentage are $22.32 \%, 25 \%$ and $8.93 \%$.

Let us see some examples:

(1) This great Nation will endure as it has endured, will revive and will prosper. (Sample 1)

(2) In this process evil things formerly accepted will not be so easily condoned. Hard-headedness will not so easily excuse hardheartedness. We are moving toward an era of good feeling. But we realize that there can be no era of good feeling save among men of good will. (Sample 2)

(3) The preservation of the spirit and faith of the Nation does, and will furnish the highest justification for every sacrifice that we may make in the cause of national defense. (Sample 3)

(4) We can and we will achieve such a peace. (Sample4)

All the above four examples are modalized by "will" and they express extents of probability. In (1) Roosevelt gave his audience the encouraging information about what the U.S.A. will be in the future according to his firm confidence or intention on the basis of American history. In his opinion, the great nation America could succeed in getting through hardships in the past. Then, it is the same with America this time. He used the modal operator will, a median value probability to modalize this clause. This clause is the implicit subjective. It is equivalent to Great America is probable to hold the line as it has done, probable to return to normal and to thrive. In the opening of inaugural address, Roosevelt applied the sentence modalized by three will to express his optimism about American future just like every president of the U.S.A. held, which encouraged the audience in the Great Depression and made them regain confidence. The tactic use of three will can help the speaker Roosevelt attract the audience from the beginning and make the audience feel more comfortably to accept and support his opinion that based on the most powerful country and the finest democracy style, Americans can conquer the depressing situation at last.

In (2) after Roosevelt's new policy, the U.S.A. walked out of Great Depression and returned to prosper as Roosevelt expected in 1933. But in the second inaugural addresses in 1937, Roosevelt pointed out that despite economic recovery, a serious moral problem arose day by day. Old individualism still permeated in the current complex civilization. Dulled conscience, irresponsibility, and ruthless self-interest already reappear. Roosevelt called on Americans to cling to the spirit of the nation-democracy to change the moral climate of America. Americans should help each other to reach common prosperity. Example (2) is also modalized by will, a median value probability, which is equivalent to probably. The clause is equivalent to In this process evil things formerly accepted is probably hard to be forgiven. Hard-headedness is probably hard to excuse hardheartedness. Roosevelt created an implicit subjective clause with the use of two will to express his judgment about the existence of bad morals. He was warning the hearers that the bad morals were not easily be abandoned. Such symptoms of prosperity may become portents of disaster. We Americans should be on the alert and cultivate good-will to solve the problem. The two will, median degree of certainty, leave a room for the audience to disagree his statement. By mitigating his statement, the modalized will can help Roosevelt intrude his attitude in a more acceptable manner.

In 1941, Roosevelt focused on military buildup. Faced with the frequent wars, he appealed the whole nation to unite together to defend the great country. Every sacrifice is to protect and to consolidate the integrity of democracy. Example (3) has the orientation of subjectivity and implicitness. In this critical period, Roosevelt used a median modalized expression to build an desirable relationship with the audience so as to mobilize the people. At last, he conveyed his policy successfully.

Example (4) has the orientation of subjective and explicit. The median value probability "will" modalizes this clause as We can and we probably achieve such a peace. Lynos agrees that will can be employed in sentences with an obvious modal use of the "promissive", in which the speaker puts himself forward as the guarantor, as it were, of the truth or the occurrence of the event he refers to.(Lyons, 1977) That is to say, will has the use of showing force of will. In (4) it is obvious to show Roosevelt's strong feeling. He promised to the audience that Americans had the ability to achieve peace under the leadership of his and his administration.

\section{Usuality}

Usuality means that how frequently the proposition is true. They include always/ sometimes/ often/ never/ ever/ seldom/ rarely. In general, the expression of usuality occurs infrequently in addresses. In our samples, there are few modal adjuncts of modality appearing. The expression of usuality has portion of $5.69 \%$ and is realized only by modal adjunct always and sometimes, which appear three times and three times respectively. Though its infrequency, the expression of usuality can help to reveal the speakers' judgment and attitude on the linguistic event to some extent. Let's see the examples: 
(5) In that purpose we have been helped by achievements of mind and spirit. Old truths have been relearned; untruths have been unlearned. We have always known that heedless self-interest was bad morals; we know now that it is bad economics. (Sample 2)

(6) Today we reconsecrate our country to long-cherished ideals in a suddenly changed civilization. In every land there are always at work forces that drive men apart and forces that draw men together. (Sample 2)

(7) I remember that my old schoolmaster, Dr. Peabody, said, in days that seemed to us then to be secure and untroubled:" Things in life will not always run smoothly. Sometimes we will be rising toward the heights---then all will seem to reverse itself and start downward. The great fact to remember is that the trend of civilization itself is forever upward; that a line drawn through the middle of the peaks and the valleys of the centuries always has an upward trend." (Sample 4)

The above three examples are the few ones containing adjuncts of usuality which function as modality in Roosevelt's inaugural addresses. In Sample 2, Roosevelt claimed that the four-year efforts made the exercise of all power more democratic. The old order of things had been changed. The achievement of mind and spirit of American democracy had built a more enduring structure for the better use of future generations on the old foundations. Only pursuit of personal interest did not do any good to the development of economy and country. America should get a clear understanding of the fact forever. Here, in example (5), always means all through past until now. The union of always and the present perfect shows that Americans recognize the truth from the past to now that mere self-interest is bad morals. Even in the future, America should comply with the truth. Always, a high value adjunct, reflects the high frequency that the proposition is true and contributes to emphasize the force of his statement. At the same time, the modal adjunct always makes Roosevelt's attitude very clear that America won't be manipulated by bad economics.

Similarly, in example (6), the use of always affirms the high frequency of the proposition that in any nation, there exist such forces alienating people or uniting people. Based on the objective statement, Roosevelt brought up his expectation that in their seeking for economic and political progress as a nation, they should go up together, or else, they all go down, as one people. He employed the high value adjunct to stress his objectivity of his statement so as to make the audience easier to accept his analysis. With the objective fact, Roosevelt called on the whole nation to bind together. So the use of always helps to underline the enforcement of his expectation.

In the fourth inaugural address, Roosevelt aimed at expressing his own viewpoint by quoting his old schoolmaster's remarks skillfully. He believed that life was impossible to go successfully all the time. It was very likely that we came across failure just after we gained success. However, the trend of civilization was upward forever. In example (7), the first always is united with "not". The negative meaning of a high value adjunct decreases the frequency that things in life will run smoothly. This collocation reflects the rationality of the statement. Sometimes means now and then or on some occasions. It is a low value adjunct. The use of sometimes does not deny the probability of success but advance blandly the possibility of failure. The speaker expressed his evaluation at the time of speaking so that he would not hurt the audience's feelings in order that the audience was more prone to accept this fact. The second always highlights the proposition that the trend of civilization itself is forever upward. It is helpful to lay stress on the force of the speaker's belief. The alternate collocation of high value adjunct always and low value adjunct sometimes reveals the speaker's judgment and attitude on the linguistic level. Roosevelt selected these remarks in his inaugural address not only to speak up his great belief in American essential democracy but also to attract audience's attention, inspire audience to run after democracy and peace and push the address to a new high.

\section{B. Modulation}

\section{Obligation}

From the statistics above, it can be seen that the expression of obligation covers $18.70 \%$ of the total. The application of such expressions signals the speaker's degree of pressure on the audience to take positive action. In the four samples, they are mainly expressed by finite modal operators must, should and have to. Must, need, should and have to appear 8times, once, once and once respectively and their corresponding percentage are $14.29 \%, 0.89 \%, 0.89 \%$ and $0.89 \%$. For examples:

(8) Finally, in our progress toward a resumption of work we require two safeguards against a return of the evils of the old order; there must be a strict supervision of all banking and credits and investments; there must be an end to speculation with other people's money, and there must be provision for an adequate but sound currency. (Sample 1)

(9) To do this we knew that we must find practical controls over blind economic forces and blindly selfish men. (Sample 2)

(10) We know that we still have far to go; that we must more greatly build the security and the opportunity and the knowledge of every citizen, in the measure justified by the resources and the capacity of the land. (Sample 3)

(11) We may make mistakes--- but they must never be mistakes which result from faintness of heart or abandonment of moral principle. (Sample 4)

All the above 4 examples are modulated, and they express degrees of obligation. They are modulated by must, a high value modal, meaning required to. During the Great Depression, Roosevelt encouraged the whole nation with his toughness and optimism that the bleak situation was temporary and several measures could help America recover. But there were some indispensable conditions. He employed three must in example (8) to give these suggestion. Example (8) is equivalent to There are required to be a strict supervision ...there are required to be an end to speculation ...there are 
required to be offer for ... Three must show high desirability of the proposals. In the modulated process, Roosevelt's attitude is enforced on the audience in an objective and implicit way, which influence the audience's opinion and action. By giving an irresistible suggestion with high value modal must, he was trying to convince the people that only when American politics are requested to make necessary changes at once, America were able to recover from depression.

In the second inaugural address, Roosevelt gave credit for American exciting recovery from Great Depression and spoke high of him, his party and the entire nation. Nevertheless, he observed some worrying social issue that conflict exists between the individual and the ever-rising problems of a complex civilization. So in the opening of the inaugural address, he raised an irresistible command that to do this we knew that we were required to find practical controls over blind economic forces and blindly selfish men. Roosevelt used one must to attach weight to the conflict and urge the audience to take positive action to solve the issue. This command in example (9) was the request to his administration as well as the hope to all the Americans. The high value obligation lays a tone of great urgency for the following address.

As for example (10), by using high value modal must, Roosevelt commanded subjectively and explicitly his administration to take efficient and quick measures to improve people's living standard and environment. The modulated clause reflects Roosevelt's determination and obligation and presidential power absolutely.

In Sample 4, Roosevelt pronounced that America should achieve an honorable and durable peace. He admitted objectively that in the process, making mistakes was understandable and ordinary. But these mistakes were restricted to be the result of faintness of heart or abandonment of moral principle. Here, he united the high value obligation must with never to play a strongly emphatic role in example (10). While reminding the audience of this point, Roosevelt succeeded deepening the force of his judgment to the audience objectively and implicitly.

When analyzing must, we need to take "should, have to, need" into consideration. Should, have to and need all only appear once but have degrees of obligation, which expresses various interpersonal functions and strong emotional appeals.

\section{Inclination}

Inclination means in what degree the speaker is willing to offer. In our samples, expression of inclination appears frequently, covering $13.01 \%$. Roosevelt aims to emphasize his willingness to do something for his country and people. Generally, they are mainly realized by finite modal operators or adjectives. In the samples, they are mostly realized by modal operator shall appearing twenty times and only three passive verbs or adjectives are used.

(12) There are the lines of attack. I shall presently urge upon a new Congress in special session detailed measures for their fulfillment, and I shall seek the immediate assistance of the several States. (Sample 1)

(13) While this duty rests upon me I shall do my utmost to speak their purpose and to do their will .(Sample 2)

(14) We shall strive for perfection. We shall not achieve it immediately--- but we still shall strive. (Sample 4)

Examples (12) and (13) are modulated and express degrees of inclination. In Sample 1, Roosevelt thought that in the resumption of work, there were possible to be various blocks. Example (12) uses two shall to express median inclination of such a determination that he was sure to fulfill the presidential duty to impel Congress to take positive action and ask States to offer help in an explicit and subjective way. The modulated clause is equivalent to $I$ am determined to urge on a new Congress at once ... and I am determined to seek ... Similarly, example (13) has the orientation of explicit and subjective and it is modulated by shall, a median value inclination. It is equivalent to $I$ am determined to do my utmost to speak their purpose ... At the end of inaugural address, like other presidents, Roosevelt put great emphasis on his strong willingness to do everything for his country and people. In the two examples, shall reflects Roosevelt's heavy sense of responsibility for America and Americans. The use of modal shall also strengthens the support and confidence from the audience and the whole national people.

In addition, according to Sample (4), we know Roosevelt claimed that the purpose of war was to achieve perfect peace at home and abroad. He had great confidence in Americans' capability of gaining peace. With careful study, example (14) might be special sentences, for there are three shall and all shall do not express inclination. The first and third shall are modulation and the second shall is modalization. The sentences means We have determined to strive for perfection. We are probable not to achieve it at once --- but we are determined to strive. Obviously, The first and third shall show the unshakable determination of his, his party and contemporary Americans to fight for peace. Although the road was uneven, Americans still stuck to it. Here, modal operator shall is a median value inclination. And the second shall is a median value probability, which is equal to be probable. It reflects the objectivity that there exist difficulties during obtaining peace. This kind of alternate application helps tactfully Roosevelt to convey his willingness on validation basis in order to encourage and inspire the whole nation to strive for peace and stand for his policy.

Interpersonal Metaphor does good to improve dynamically the emotional interaction between the speaker and the audience.

\section{CONCLUSION}

Franklin D. Roosevelt was one of the three greatest presidents in American history, who held the presidential post for four terms. His political achievements won his high supporting rate throughout the United States. This article takes Franklin D. Roosevelt's four inaugural speeches as objects of study, and mainly uses the modality system in Halliday's systemic functional grammar as theoretical framework. Our study shows that Roosevelt prefers modalization to 
modulation, which takes up $68.29 \%$ and $31.71 \%$ respectively. It shows that Roosevelt gives more propositions than proposals in these addresses, and what Roosevelt conveys to the hearers more is information, while request and command is relatively less. In terms of usuality, there are few modal adjuncts of modality taking up only $5.69 \%$ and is realized only by modal adjunct always and sometimes. As for modulation, obligation covers $18.70 \%$ signaling the speaker's degree of pressure on the audience to take positive action, and inclination appears frequently, covering $13.01 \%$, and is mainly realized by finite modal operators or adjectives, showing Roosevelt's willingness to do something for his country and people. Through these sparkling speeches, his wisdom and intelligence, capability and responsibility, prestige and power are fully demonstrated.

\section{REFERENCES}

[1] Campbell, K, \& Jamieson, K. (1990). Deeds Done in Words: Presidential Rhetoric and the Genres of Governance. Chicago: University of Chicago Press.

[2] Halliday, M.A.K. (2000). An Introduction to Functional Grammar $2^{\text {nd }}$ Edition. Beijing: Foreign Language Teaching and Research Press.

[3] Hoye, L. (1997). Adverbs and Modality in English. London \& New York: Longman Group Ltd.

[4] Lemke. J. L. (1992). Interpersonal Meaning in Discourse. London and New York: Pinter.

[5] Thompson, G. (2000). Introducing Functional Grammar. Beijing: Foreign Language Teaching and Research Press.

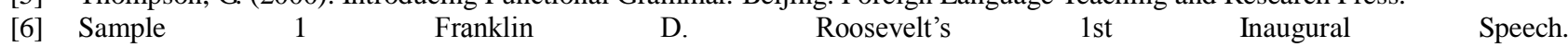
http://www.for68.com/new/2006/1/wa4480164839311600216100-0.htm. Accessed 10/5/2017.

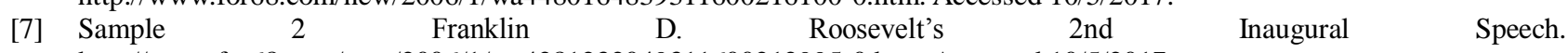
http://www.for68.com/new/2006/1/wa4281232049311600212995-0.htm. Accessed 10/5/2017.

[8] Sample 3 Franklin D. Roosevelt's 3rd Inaugural Speech. http://www.for68.com/new/2006/1/wa42172149311600213662-0.htm. Accessed 10/10/2017.

[9] Sample 4 Franklin 4 D. $\quad$ Roosevelt's 4 4th $\quad$ Inaugural http://www.for68.com/new/2006/1/wa292217124931160024046-0.htm.. Accessed 10/10/2017.

Xiaoli Dou is currently a lecturer of English at School of Foreign Languages and Literatures, Chongqing Normal University, China, and her research interests cover foreign language teaching and literary stylistics.

Wendi Yang is currently a treasury services Officer at Chengdu Qinglong Subbranch, Industrial and Commercial Bank of China, LTD, and her research interests cover functional stylistics and international finance. 